\title{
Legal Responses to Drought in Kansas
}

\author{
John C. Peck ${ }^{*}$
}

\section{INTRODUCTION}

In this article I examine legal responses to drought in Kansas since statehood in $1861^{1}$ by persons and various levels of government. An article about drought should probably use or create a definition for the term. Although precision in such definitions can be important in some legal contexts, ${ }^{2}$ it is not required here. The term drought has many meanings. $^{3}$ I have not adopted any one definition against which to examine the legal responses, but rather have chosen to accept and use some periods of Kansas drought identified by experts.

Even after identifying drought periods since statehood, one finds it difficult to discern whether a legal event during or following a drought has necessarily been a direct response to a particular drought or instead just a part of sound, long-term water resources planning efforts. ${ }^{4}$ Some

* Connell Teaching Professor of Law, University of Kansas. I am indebted to Miriam Friesen of the University of Kansas School of Law class of 2014 for her invaluable research.

1. Information about droughts occurring long before statehood is available. See generally William van Royen, Prehistoric Droughts in the Central Great Plains, 27 GeOGRAPHICAL ReV. 637 (1937) (discussing two serious drought periods approximately between 8000 to 5000 B.C. and 2000 to 600 B.C.); Nat'l Oceanic \& Atmospheric Admin. Paleoclimatology Program, North American Drought: A Paleo Perspective-The Data, NOAA NAT'L Climatic DATA CTR., http://www.ncdc. noaa.gov/paleo/drought/drght_data.html (last updated Nov. 12, 2003) ("[D]ata . . . document drought conditions back to the beginning of the Holocene (10,000 years before present)."); ANTHONY L. Lazell, Kan. GeOlOGical Surv., Open-File ReP. NO. 2012-18, A ThOusand Years of DROUGHT AND Climatic VARIability IN KANSAS: IMPLiCATIONS FOR WATER RESOURCES MANAGEMENT (2012), available at http://www.kgs.ku.edu/Hydro/Publications/2012/OFR12_18/ KGS_OF_2012-18.pdf (providing graphs of drought periods based on tree-ring reconstruction since before the year 1000 A.D.).

2. See, e.g., Carolyn Cadena, A Minute of Clarity after Decades of Confusion: "Extraordinary Drought" in the Lower Rio Grande Basin, 24 GEO. INT'L ENVTL. L. REV. 605 (2012) (discussing problems regarding the 1944 Treaty Relating to the Utilization of Waters of the Colorado and Tijuana Rivers and the Rio Grande during recent drought years and the desirability of defining a treaty term- "extraordinary drought"- the occurrence of which under the treaty language creates some relief to one country or the other from its normal treaty obligations).

3. See infra Part II.A.

4. "While momentarily important the impression should not be left that the immediate exigencies [of floods and moisture deficiencies] are alone responsible for the broad interest in water problems. Under normal weather conditions thinking persons have been aware of the growing 
state water planning efforts, such as the State Water Plan in Kansas, ${ }^{5}$ involve attempts to deal with droughts generally.

This article is essentially retrospective and descriptive, not prospective and analytical. Analyses of state drought programs outside Kansas have been conducted, including a recent one published by the American Water Resources Association, which described and analyzed case studies in proactive drought management in Texas, Oregon, Hawaii, and Oklahoma. ${ }^{6}$ Such a study of responses to drought in Kansas, along with comparative analysis with other states' drought management techniques and experience, would be a worthy project.

demands placed upon this critical resource by industrialization, urbanization, irrigation, and the patterns of home living." Paul E. Malone, Preface to RICHARD PFISTER, WATER RESOURCES AND IRRIGATION (Univ. of Kan. Sch. of Bus.-Bureau of Bus. Research, Economic Development in Southwestern Kansas Part IV, 1955).

5. State Water Resource Planning Act, Kan. Stat. AnN. §§ 82a-901 to -954 (2013). Kansas has conducted water resources planning since 1927 and has had a dynamic process since 1984. See John C. Peck \& Doris K. Nagle, Legal Aspects of Kansas Water Resources Planning, 37 U. KAN. L. REV. 199 (1989) (discussing history and legal responses to emerging issues in Kansas water planning efforts). And Governor Brownback has recently called for the development of a "50-Year Vision for Kansas Water" to deal with problems of Ogallala Aquifer depletion, reservoir sedimentation, and drought. The 50-Year Water Visioning Team, Kan. Water Off., The 50-Year Vision for Kansas Water (2013), available at http://www.kwo.org/50_Year_Vision /Editorial\%20Column.pdf. But see BEN CHOU WITH JENNA SCHROEDER, NAT. RES. DEF. COUNCIL, REAdy or Not: An Evaluation of State Climate and Water PREPAREDNess Planning 3 fig. ES-2 (2012), available at http://www.nrdc.org/water/readiness/files/Water-Readiness-issue-brief.pdf (ranking states in preparedness for climate change, with Kansas ranked in the fourth, lowest category; however, the NRDC recognizes that Kansas has some existing programs and policies that, if "recognized as climate change adaptation tools, could prove beneficial for climate preparedness").

Sometimes a state's legal response is clearly directed to drought. See, e.g., Richard Frank, California Enacts Emergency Drought Legislation, LEGAL PLANET, Mar. 4, 2012, http://legalplanet.org/2014/03/04/california-enacts-emergency-drought-legislation/. In response to the recent and on-going drought in California, said to be "unprecedented" and the "worst drought in recorded California history," the California Legislature enacted S.B. 103 and S.B. 104. Id. These bills provide, inter alia, millions of dollars for drought relief efforts, and provisions to strengthen the state's water rights enforcement system and to empower state regulators to require groundwater replenishment using recycled water. $I d$.

6. Lauren Dennis, Am. Water Res. Ass'N, Proactive Flood and Drought MANAGEMENT: A SELECTION OF APPLIED STRATEGIES \& LESSONS LEARNED FROM AROUND THE UNITED STATES (Brenda Bateman et al. eds., 2013), available at http://www.awra.org/webinars/ AWRA_report_proactive_flood_drought_final.pdf. 


\section{KANSAS DROUGHT PERIODS}

\section{A. Defining Drought ${ }^{7}$}

One occasionally hears or reads the word drouth in place of drought. Both words are shown as alternates in some dictionaries. ${ }^{8}$ Drouth is a Scottish word meaning thirst, pronounced "drooth" thirsty, or a heavy drinker. ${ }^{10}$ A New York Times article stated, "Like many others, [University of Illinois lecturer Pearl Goodman] had heard drought rhyme with snout, but never with mouth. Millions of Americans, in and out of the arid Farm Belt, however, refer to the 'drouth' that has ruined crops this summer." I1 Interestingly, legal

7. Numerous sources of drought information are available in print and online. See, e.g., KAN. WATER Res. BD., RePORT to the 1955 State Legislature, Water in Kansas 17 (1955) (considering various definitions of drought with respect to state precipitation data; authored by predecessor agency to current Kansas Water Office); KAN. WATER OFF., http://www.kwo.org (last visited Mar. 8, 2014) (detailing state water planning, policy, marketing, and coordination information); Wichita Kan. Weather Forecast Off., Nat'l Weather Serv., NWS Wichita Drought Page: Comparing Past Droughts, NAT'L WeATHER SERV., NAT'L OCEANIC \& ATMOSPheriC ADMIN., http://www.crh.noaa.gov/ict/?n=drought (last updated Dec. 18, 2013) (describing historical drought severity in Kansas using Palmer Drought Severity Index); Kan. Geological SuRv., Geohydrology Section and Water Resources Information, http://www.kgs.ku.edu/Hydro/hydroIndex. html (last updated Feb. 13, 2014) (providing information regarding state's water resources); KAN. RURAL CTR., http://www.kansasruralcenter.org (last visited Mar. 8, 2014) (offering information regarding agricultural developments); Agricultural News and Articles, Commodity Markets \& Prices, AgWeb, http://www.agweb.com (last visited Mar. 8, 2014) (presenting national agricultural news). Literature also includes reference to drought or famine. See, e.g., Genesis 41:1-45:25 (telling the story of Joseph and the seven-year famine in Egypt and elsewhere); Samuel T. Coleridge, The Rime of the Ancient Mariner, in LyRICAL BALLADS AND OTHER POEMS 207, 211-12 (Wordsworth Editions 2003) (William Wordsworth et al. eds., 1802) (“. . . through utter drought, $[/]$... Water, water, everywhere, [/] Nor any drop to drink."); JOHN STEINBECK, THE GRAPES OF WRATH (Penguin Books 2006) (1939) (chronicling the story of one Oklahoma farm family during the Dust Bowl of the 1930s); Frank Halliwell, Drought's End, FRANK HALLIWELL's POETRY PAGES, http://frankhalliwell.tripod.com/frank3.html\#Drought's End (last visited Mar. 8, 2014); Juan Olivarez, End of The Drought, POEMHunTER, http://www.poemhunter.com/poem/endof-the-drought/ (last modified Aug. 25, 2010).

8. See, e.g., Webster's New Collegiate Dictionary 347 (8th ed. 1981).

9. See Folk-ETymology: A Dictionary of CoRrupted Words 104 (Haskell House Publishers Ltd., 1882); Iseabail Macleod \& Pauline Cairns, The Essential Scots DiCTIONARY: SCOTS-ENGLISH, ENGLISH-SCOTS 40 (Edinburg Univ. Press, 2004); RoBERT J. HigGS, Ambrose N. Manning, \& Jim Wayne Miller, 2 Appalachia Inside Out: Culture and Custom 511 (Univ. Tenn. Press 1996).

10. Ulster-Scots, Words and Phrases: “drouth”, BBC, http://www.bbc.co.uk/ulsterscots/words /drouth (last visited Mar. 3, 2014).

11. Reuters, Pronouncing a Dry Spell, N.Y. TiMES (Aug. 15, 1988), http://www.nytimes.com/1988/08/15/us/pronouncing-a-dry-spell.html. An article on the Kansas Historical Society website states that the best known work of painter Henry Worrall, and "the biggest single advertisement Kansas ever had," was his "whimsical" sketch dubbed Drouthy Kansas. Rebecca Martin, Cool Things-Drouthy Kansas Painting, KANSAPEDIA COLLECTION OF KAN. Hist. 
research finds drouth rather than drought in some Kansas appellate court opinions, ${ }^{12}$ causing one to miss potentially relevant cases if one searches only for cases dealing with drought. ${ }^{13}$

Drought differs from famine and aridity. Famine is an "extreme scarcity of food," 14 and famine can result from drought. Aridity is "a permanent climatic condition in a region, whereas drought is a temporary lack of moisture." 15 People speak of the arid West or "Dry West" and the "Humid East," with the 100th meridian commonly given as the dividing line. ${ }^{16}$ Early maps of the upper West-central United States, including what is now Kansas, show the region as "the Great American Desert," 17 and one early detractor described this land as unfit "for settlement or habitation.... unproductive.... like a barren waste.... [that] will not support cattle, or sheep, or anything pertaining to the grazing business."

The common dictionary definitions of drought as "a prolonged period of dryness,"19 "departures below normal precipitation over periods of varying duration," 20 or as "a prolonged period of abnormally low rainfall, leading to a shortage of water," 21 are too simple and vague to be

SoC'Y, http://www.kshs.org/kansapedia/cool-things-drouthy-kansas-painting/10123 (last modified Feb. 2011). Completed in 1868 to counter the "aggravating [disparaging] remarks" of former associates from Cincinnati, the sketch depicted bountiful rainfall and lush corn and grape crops. Id. See also Victoria Foth, Kan. Nat. Res. Council, Rain and Riches Will Follow the Plow, in WATER AND THE MAKING OF KANSAS (2010), available at http://www.knrc.ws/watermk03.htm (noting that promoters used Wornall's painting "to convince settlers that Kansas offered abundant water").

12. See, e.g., Weaver v. Beech Aircraft Corp., 303 P.2d 159, 162 (1956).

13. Computer searches also find cases involving people named Drought. See, e.g., Galbreath v. Drought, 1883 WL 824 (Kan. 1833); Viking Refrigerator \& Mfg. Co. v. Crawford, 114 P. 240 (Kan. 1911).

14. Famine Definition, OXFORD DICTIONARIES, http://www.oxforddictionaries.com/us/ definition/american_english/famine (last visited Mar. 8, 2014).

15. Thomas V. Cech, Principles of Water Resources: History, Development, Management, and Policy 66 (John Wiley \& Sons, 3d ed. 2010). The 1936 Bob Nolan country music song "Cool Water"- “All day I've faced a barren waste, without the taste of water, cool water ...")- - seems to be referring to aridity, not drought, because it "was inspired by the Arizona desert after [Nolan] came there from the backwoods of Canada." The Story Behind the Song-Cool Water, COUNTRY MUSIC TREASURES, http://www.countrymusictreasures.com/storybehindthesong/ cool-water.html (last visited Mar. 8, 2014).

16. See, e.g., The Humid-Arid Transition, ENCYClOPEDIA BRITANNICA's GuIDE TO AMERICAN PRESIDENTS, http://britannica.com/presidents/article-77966 (last visited Mar. 8, 2014).

17. $I d$.

18. Grant Mitchell, The Sixth Principal Meridian, 11 The KAN. AbSTRaCter 6 (Jan. 1937) (describing an 1861 speech by Senator Green of Missouri in the United States Senate).

19. WebsteR's New Collegiate Dictionary 347 (8th ed. 1981).

20. KAN. WATER RES. BD., supra note 7, at 17.

21. CONCISE OXFORD ENGLISH DiCTIONARY 439 (12th ed. 2011). 
of much use, in part because "[d]rought is relative to a particular location." 22 The Kansas Water Office defines drought as "[a] period of abnormally dry weather that persists long enough to produce serious economic, environmental or social impacts." ${ }^{, 23}$ More specific definitions exist, such as "[p]recipitation less than 75 percent of the average." ${ }^{24}$ The U.S. National Weather Service's definition is more comprehensive:

Drought is a deficiency in precipitation over an extended period, usually a season or more, resulting in a water shortage causing adverse impacts on vegetation, animals, and/or people. $\left[{ }^{25}\right]$ It is a normal, recurrent feature of climate that occurs in virtually all climate zones, from very wet to very dry. Drought is a temporary aberration from normal climatic conditions, thus it can vary significantly from one region to another. ${ }^{26}$

Droughts can be subdivided into meteorological drought, ${ }^{27}$ agricultural drought, ${ }^{28}$ hydrological drought, ${ }^{29}$ and socioeconomic drought. ${ }^{30}$

22. CECH, supra note 15 , at 66 .

23. Governor's Drought Response Team, Kan. Water OfF., Kansas Drought OPERATIONS PLAN 1 (2012), available at http://www.kwo.org/reports_publications/Drought/rpt_ drought_op_plan_gdrt_draft_withapendi_062912_dc_kf.pdf.

24. Jamie Dysart, Hope for the Best, Plan for the Worst: Graziers Focus on Drought Planning, 247 KAN. RuRAL CTR. RuRAL PAPERS 1 (Jan.-Feb. 2013) (quoting David Kraft, state rangeland management specialist for the Natural Resources Conservation Service).

25. Drought periods solely over oceans far from land may have little direct effect on people (except perhaps the lonely seafarer who is trying to survive with rainwater-see, e.g., Coleridge, supra note 7), but El Niños and La Niñas, which involve "fluctuations in temperature between the ocean and the atmosphere in the east-central Equatorial pacific," may cause drier than average conditions in parts of the U.S. What Are El Niño and La Niña?, NAT'L OCEAN SURV., NAT'L OCEANIC \& ATMOSPHERIC ADMIN., http://oceanservice.noaa.gov/facts/ninonina.html (last modified Jan. 11, 2013). See also ENSO and Drought Forecasting, NAT'L Drought Mitigation CTR., http://drought.unl.edu/DroughtBasics/ENSOandForecasting.aspx (last visited Mar. 8, 2014) (defining El Niño and its drought implications).

26. NAT'L WeAther Serv., NAT'L OCEANIC \& ATMOSPheric Admin., Drought Public FACT SHEET 1 (Aug. 2006), available at http://www.nws.noaa.gov/om/brochures/climate/Drought. pdf.

27. Id. ("Meteorological drought is usually defined based on the degree of dryness (in comparison to some 'normal' or average) and the duration of the dry period. Drought onset generally occurs with a meteorological drought.").

28. Id. ("Agricultural drought links various characteristics of meteorological (or hydrological) drought to agricultural impacts, focusing on precipitation shortages, soil water deficits, reduced ground water or reservoir levels needed for irrigation, and so forth."). "[A]griculturalists ... point out that drought occurs when there is a shortage of water for optimum growth and development of desirable plants or crops." KAN. WATER RES. BD., supra note 7, at 17. Thus a farmer might claim a drought period to be occurring after only a few weeks of little or no precipitation if, after germination, the plant does not develop adequately.

29. NAT'L WEATHER SERV., supra note 26, at 1 ("Hydrological drought usually occurs following periods of extended precipitation shortfalls that impact water supply (i.e., streamflow, 


\section{B. Kansas Drought Periods}

Old government reports, newspaper articles and editorials, and popular literature provide commentary about periods of dryness that have caused direct, ill effects in Kansas. Nineteenth century annual yearbooks published by the Kansas Board of Agriculture ${ }^{31}$ and the Kansas Historical Quarterly ${ }^{32}$ describe precipitation, or the lack thereof, with specificity and the effects on crop yields and on the early settlers during drought years. Included are descriptions of dust storms resulting from those droughts. ${ }^{33}$ In 1888, Emporia Gazette Editor William Allen White wrote and published The Story of Aqua Pura, a short story about a small western Kansas town that flourished until several years of drought totally devastated and demolished the town. ${ }^{34}$

Area-wise, Kansas is a relatively large state with average precipitation that varies from over forty inches in the southeast corner of the state to less than twenty inches along the western border with Colorado. ${ }^{35}$ Speaking of statewide drought might assume that the drought would somehow be uniform across the state. Descriptions of droughts from the Kansas Board of Agriculture Annual Reports in the nineteenth century show localized variation. ${ }^{36}$ And the periodically

reservoir and lake levels, ground water), potentially resulting in significant societal impacts. Because regions are interconnected by hydrologic systems, the impact of meteorological drought may extend well beyond the borders of the precipitation-deficient area.").

30. $\mathrm{CECH}$, supra note 15 , at 67 (defining socioeconomic drought as "[i]nadequate water supplies to serve local residents").

31. See, e.g., Kan. Bd. of Agric., The Third Annual Report to the Legislature of KANSAS FOR THE YEAR 1874, at 94-102 (1874) (displaying detailed "tables of rainfall in Kansas"); Kan. BD. OF Agric., First Biennial Report of the State BoARd of Agriculture to the LEGISLATURE OF THE STATE OF KANSAS FOR THE YEARS 1977-1878, at 426-29 (1878) (presenting state precipitation data).

32. See, e.g., James C. Malin, Dust Storms: Part One, 1850-1860, 14 KAN. HIST. Q. 129, 129 33 (1946) (describing the "great drought" of 1860 that began in 1853 or 1854); James C. Malin, Dust Storms: Part Two, 1861-1880, 14 KAN. HIST. Q. 265, 265-96 (1946) (describing a "prolonged severe drought, eight years of it, with only slight interruptions" beginning in 1873).

33. See, e.g., Dust Storms: Part One, 1850-1860, supra note 32; Dust Storms: Part Two, 1861-1880, supra note 32.

34. William Allen White, The Story of Aqua Pura, in The ReAl Issue: A Book of KANSAS STORIES 22, 22-38 (Chicago, Way \& Williams 1897), available at http://www.kancoll.org/books/ white/whchap02.htm.

35. Kan. GeOlogical Surv., KGS Special Map 9-Groundwater and Precipitation in Kansas, http://www.kgs.ku.edu/Hydro/hydroSheetMap.html (last updated Nov. 8, 1996).

36. See, e.g., Sgt. T.B. Jennings, Kansas Weather Service: Rain Charts and Crop-Weather Bulletins, in KAN. BD. OF Agric., SiXth BIENNIAL REPORT OF THE STATE BOARD OF AgRiculture TO THE LEGISLATURE OF THE STATE OF KANSAS FOR THE YEARS 1887-1888, at 212, 212-13 (1888) ("The rainfall has been abundant east of the 98th meridian. Good rains have fallen in Comanche, 
produced U.S. Drought Monitor maps of the National Oceanic and Atmospheric Administration (NOAA) show much variation in precipitation, indicating that some parts of the state may be suffering from drought while other parts are enjoying adequate precipitation. ${ }^{37}$ Figure $1^{38}$ is a graph produced by the National Climate Data Center of NOAA and shown on the NOAA website. The graph shows historic droughts since 1895 for the state as a whole based on the Palmer Drought Index. ${ }^{39}$

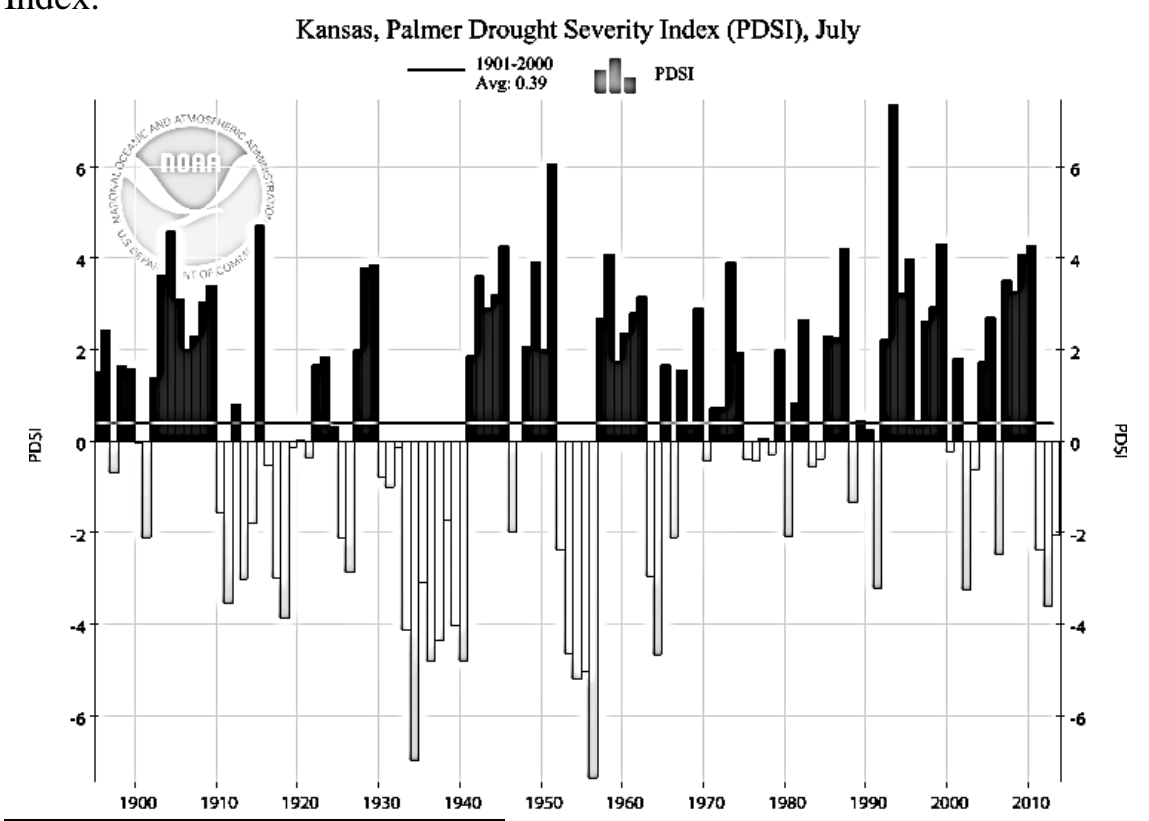

Barber and Harper, thence north to and including Russell and Ellsworth, except in Stafford, where the drouth continues. Heavy rains in Graham, good rains from Ness and Garfield to the west line of the State. The rain is deficient in ... [eight listed counties] . . . while in the rest of the counties fair rains have fallen.").

37. See, e.g., Climate Prediction Ctr., Drought Information: U.S. Drought Monitor, NAT'L WEATHER SERV., NAT'L OCEANIC \& ATMOSPHERIC ADMIN., http://www.cpc.ncep.noaa.gov/ products/Drought/ (last visited Mar. 11, 2014) (displaying daily drought conditions; the map for March 11, 2014 shows "extreme drought" in parts of far western Kansas and only "abnormally dry" conditions over most of eastern Kansas).

38. Wichita Kan. Weather Forecast Off., supra note 7.

39. The Palmer Drought Severity Index, "known operationally as the Palmer Drought Index $(P D I)$ attempts to measure the duration and intensity of the long-term drought-inducing circulation patterns." Nat'l Climatic Data Ctr., Climate of 2013-April U.S. Palmer Drought Indices, NAT'L ATMOSPHERIC \& OCEANIC ADMIN., http://www.crh.noaa.gov/images/ict/wxstory/2013/ADK /multigraph(5).png (last updated May 20, 2014). An index of " $\geq 4.00$ " indicates extremely wet conditions, while an index of " $\leq-4.00$ " shows extreme drought conditions. William M. Alley, The Palmer Drought Severity Index: Limitations and Assumptions, 23 J. ClimATE \& APPLIED METEOROLOGY 1100, 1102 tbl.1 (1984), http://www.engr.colostate.edu/ jsalas/classes/ce624/ Handouts/Palmer \%20Index-alley\%201984.pdf. 
For the purposes of this paper, I use eleven drought periods in Kansas, synthesized from various sources: ${ }^{40}$ three between statehood and 1900; six in the 1900s; and two in the 2000s, the latest of which is still ongoing in parts of Kansas:

\begin{tabular}{|c|c|c|}
\hline Period 1 & Period 2 & Period 3 \\
\hline $1859-1868$ & $1909-1919$ & $2002-2006$ \\
$1872-1875$ & $1929-1941$ & $2010-2014$ \\
$1892-1901$ & $1952-1957$ & \\
& $1962-1972$ & \\
& $1974-1982$ & \\
& $1988-1992$ & \\
\hline
\end{tabular}

The best data began to be accumulated after 1900, but some evidence of drought periods pre-1900 is shown in various books and articles. ${ }^{41}$

\section{LEGAL RESPONSES TO DROUGHT}

\section{A. Introduction}

This section describes some legal responses to Kansas drought. If court cases, legislation, constitutional amendments, or administrative agency actions have truly been responses to drought, they likely appear either during droughts or following reasonably soon after droughts.

To some extent, that is what the legal research shows, but as stated above, it is difficult in some cases to conclude that a specific response has resulted from drought. This is especially the case if legislation, for example, contains no preface or explanatory language or there are no interim committee reports or hearings, State Water Plan recommendations, or other accompanying evidence that clearly state the intent of the legislature. Judicial cases are typically more straightforward. The cases cited below contain the word drought and often indicate expressly that the dispute derived directly from a drought or dry period. Water right impairment cases, of course, can arise in times when there is no drought, as when an upper-stream user simply uses more than that user's

40. See, e.g., sources cited supra notes 7, 31, 32, \& 37; Kan. Water Science Ctr., Historic Droughts of Kansas, U.S. GEOLOGICAL SURV., http://ks.water.usgs.gov/historic-droughts-of-kansas (last modified Aug. 22, 2013).

41. See sources cited supra notes $31 \& 32$. 
permitted quantity. ${ }^{42}$

These responses are presented by category-judicial, legislative, and administrative - in that order and generally chronologically within the group. While legislation has been necessary to establish administrative agencies and empower them to deal with drought, the fact that the material on these agencies is presented at the end of the section because of chronology should not be read to diminish the role of administrative agencies compared to the courts and the legislature. Indeed, over the last twenty years, these administrative responses have been very important.

\section{B. Judicial Decisions Involving Drought}

\section{The Year 1945 as the Dividing Line}

It seems logical to divide the drought cases into two groups based on the year 1945. The legislature enacted the Water Appropriation Act in $1945,{ }^{43}$ which changed the state water allocation law from a common law system (riparian doctrine of reasonable use for streams and absolute ownership doctrine for groundwater) to the prior appropriation doctrine for both streams and groundwater.

\section{Pre-1945 Cases}

Three of the four pre-1945 cases involved water right impairment claims by users on rivers, while one was a water quality case. Plaintiffs filed each case during a period of drought identified above in Part II.

In the 1905 case of Clark v. Allaman, ${ }^{44}$ a lower riparian irrigator obtained an injunction in a suit against an upper riparian irrigator. The Kansas Supreme Court observed, "The years of 1900 and 1901 were excessively dry. Then the test came, and the difficulties between the various appropriators of water arose. ${ }^{, 45}$ The court reversed the trial court's decision. ${ }^{46}$ While the drought had apparently led to the lawsuit, the outcome ultimately rested on the supreme

\footnotetext{
42. See, e.g., Weaver v. Beech Aircraft Corp., 303 P.2d 159 (Kan. 1956) (affirming order granting downstream riparian owner temporary injunction against upstream defendant's diversion of water from well).

43. 1945 Kan. Sess. Laws 665, ch. 390 (codified as amended at KAN. StAT. ANN. §§ 82a-701 to -773 (2013)).

44. 80 P. 571, 585 (Kan. 1905).

45. Id. at 573 .

46. Id. at 585 .
} 
court's decision not to replace the riparian doctrine with prior appropriation. ${ }^{47}$

Likewise, the 1936 supreme court faced a similar impairment claim in Frizell v. Bindley. ${ }^{48}$ In 1911 the plaintiff-irrigator had filed for appropriation permits to irrigate lands from a river under an 1886 statute that had ostensibly set up a system of water rights based on priority of appropriation among water users who also filed. ${ }^{49}$ The plaintiff sued other irrigators (all but one irrigating from river water), some of which had filed after the plaintiff, while others were irrigating without filing for a permit. ${ }^{50}$ After several dry seasons, there was insufficient water for all. ${ }^{51}$ The court declared the statutory filings to be irrelevant and held that the common law riparian rule of reasonable use applied, meaning that all riparian users had a right to a reasonable share of the water, irrespective of filings or date of first use. ${ }^{52}$

In 1917, the Kansas Supreme Court decided Atchison, Topeka \& Santa Fe Railway Co. v. Shriver. ${ }^{53}$ A railroad company, a riparian land owner, had sued a mill owner to enjoin destruction of a dam constructed by the railroad company during "an unprecedented drought, which the [trial] court felt impelled to classify as an act of God." 54 The supreme court affirmed the district court's refusal to order an injunction because by the time of the trial "normal conditions had been restored" and "the cause of the litigation — dearth of water resulting from excessive drought- - had ceased to exist." ${ }^{55}$

The pre-1945 water quality case was Seglem v. Skelly Oil Co. ${ }^{56}$ In Seglem, a downstream riparian owner sued an upstream industry for damages for pollution caused by discharges of brine, oil, and "noxious refuse" into the creek during a drought, making the water unfit for livestock, killing trees, and leaving sediment on bottom land. ${ }^{57}$ The supreme court reversed the jury verdict for $\$ 3,500$ against defendant. ${ }^{58}$ Acknowledging that drought may have exacerbated

47. See id. at 573-74 (characterizing the court's task as determining the "legal propriety" of the trial court's decision to apportion water "among the various claimants according to the law of prior appropriation ... rejecting altogether the rules of the common law relating to riparian rights"; concluding that, among other reasons, "the history of the [prior appropriation] rule obviously remove[s] [Kansas] from its operation.”).

48. 58 P.2d 95 (Kan. 1936).

49. Id. at 96-97. See also infra Part III.C.2. for a description of that legislation.

50. Frizell, 58 P.2d at $96-97$.

51. Id. at 96 .

52. Id. at $101-02$.

53. 166 P. 519 (Kan. 1917).

54. Id. at 519-20.

55. $I d$.

56. 65 P.2d 553 (Kan. 1937).

57. Id. at 553 .

58. Id. at 554,556 . 
the damages, the court nevertheless ruled against the plaintiff based on a twoyear statute of limitations. ${ }^{59}$

\section{Post-1945 Cases}

Likewise, the seven post-1945 cases arose during periods of drought listed in Part II. A case similar to Atchison, Topeka \& Santa Fe Railway Co. v. Shriver $^{60}$ summarized above was the 1956 Huber v. Schmidt ${ }^{61}$ case. Plaintiff, a downstream domestic user, sued an upstream irrigator for an injunction due to defendant's drying up the creek in drought conditions. ${ }^{62}$ Prior to the hearing, an eight-inch rain fell, so the trial court dismissed the suit. ${ }^{63}$ Unlike the outcome in Atchison, however, on appeal the Huber court reversed, stating that even if the rain "did occur and for the time being did saturate the soil and restore a flow of water . . . as soon as that result abated, as in ordinary course it would, then plaintiff would be in the same position as when he commenced the action." ${ }^{64}$

A 1956 impairment case was Weaver v. Beech Aircraft Corp. ${ }^{65}$ A lower riparian land owner had sued an upper owner for an injunction, claiming that the taking of all the spring water emptying into the creek was unreasonable. ${ }^{66}$ The supreme court did not apply prior appropriation principles under the 1945 Act, because apparently neither water user held an appropriation or vested right. ${ }^{67}$ The supreme court admitted that "severe drought conditions" may have affected flow in the stream and from the spring, but the defendant was taking all the water, which was unreasonable. ${ }^{68}$ The court also noted that no party had obtained appropriation rights under the 1945 Act. $^{69}$

Two post-1945 cases $^{70}$ involved groundwater, and both cases addressed and upheld the constitutionality of the 1945 Kansas Water Appropriation Act. Both

\footnotetext{
59. Id. at 555-56.

60. See supra text accompanying note 53 .

61. 299 P.2d 33 (Kan. 1956).

62. Id. at 33-34.

63. Id. at 34 .

64. $I d$.

65. 303 P.2d 159 (Kan. 1956).

66. Id. $160-61$.

67. Id. at 163 . In 1956, water users were not required to obtain a permit. Without such a permit, however, those users had no protectable water right. In 1977 the legislature first made diverting any water without a permit, except for a few limited uses, a crime. 1977 Kan. Sess. Laws 1170 , ch. 356, §2 (codified as amended at KAN. STAT. ANN. § 82a-728 (2013)).

68. 303 P. $2 d$ at 162.

69. Id. at 163 .

70. Baumann v. Smrha, 145 F. Supp. 617 (Kan. 1956); Williams v. City of Wichita, 374 P.2d 578 (Kan. 1962).
} 
cases involved "passive irrigation" or "sub-irrigation,",71 which is irrigation that uses the groundwater without resorting to pumping, in which the plant roots reach down below the water table to tap groundwater resources below. ${ }^{72}$ By creating so-called "vested rights," by land owners who were actually pumping water on the effective date of the Act, June 28, 1945. But the Act had cut off rights of land owners not actively pumping water on that date. ${ }^{74}$ Drought was not really the primary focus of either case, but in Baumann v. Smrha the supreme court acknowledged the fact that "the water table might have declined as much as four feet without pumping because of drought, but the rest of the decline must be attributed to pumping.",75

Likewise, Williams v. City of Wichita involved landowners near Wichita's municipal groundwater wells who claimed that their land values had gone down due to Wichita's wells having lowered the water table. ${ }^{76}$ The court acknowledged that the drought from 1951 to 1957 had lowered the water table to 11.38 feet below the land surface and that the water table had risen to be 5.31 feet below the land surface after the drought in $1958 .^{77}$ The court denied plaintiff's claim and upheld the Kansas Water Appropriation Act against a claim of an unconstitutional taking of property without compensation. ${ }^{78}$

The other three cases were not water right impairment cases. Rural Water District No. 6 Butler County, Kansas v. Ziegler Corp. ${ }^{79}$ was an arbitration award appeal involving liquidated damages in a contractor's delay, caused in part by drought conditions. Kansas ex rel. Meek v. Hays ${ }^{80}$ involved the question of navigability of a southeast Kansas stream and the right of canoeists to float on the stream against rights of riparian landowners. Finding that "[d]uring times of drouth, portions of Shoal Creek are impassable by even a canoe or small boat," the trial court, affirmed on appeal, held that the stream was non-navigable, thus declaring that riparian land owners also owned the bed of the stream and that

71. See Baumann, 145 F. Supp. at 620; Williams, 374 P.2d at 607.

72. G.L. ASSAWA, ELEMENTARY IRRIGATION ENGINEERING 12 (1999).

73. 1945 Kan. Sess. Laws 665, ch. 390, § 1(d) (codified as amended KAN. STAT. ANN. § 82a701(d) (2013)).

74. See id. (conditioning "vested right," in part, on "having actually ... applied" or having "engaged in the construction of works for the actual application of water to a beneficial use at the time of the passage of [the] act").

75. Baumann, 145 F. Supp. at 620.

76. Williams, 374 P.2d at 580-82.

77. Id. at 584 .

78. Id. at 595-96.

79. 677 P.2d 573, 577 (Kan. Ct. App. 1984). The arbitrator had extended the project completion date due to drought, but awarded liquidated damages for several months' delay beyond that date. $I d$. The appeals court upheld the award for the district against contractor. Id. at 580-82.

80. 785 P.2d 1356, 1358 (Kan. 1990). 
floating on the stream would constitute trespass. ${ }^{81}$ Lastly, the unpublished opinion Lierz v. Lierz involved a dispute over rights to water behind a dam on plaintiff's land under an easement agreement with defendant, the dominant tenement. ${ }^{82}$ Regarding future injury, the appeals court noted that the plaintiff needed water "only in dry years" and that the trial court had "characterized the years immediately prior to the filing of this lawsuit in 2005 as "drought conditions. ${ }^{.83}$

\section{Legislation and a Constitutional Amendment}

\section{Introduction}

Like the last section on judicial decisions, this section draws a dividing line chronologically at 1945. Some pre-1945 legislation, some post-1945 legislation, and the 1945 Water Appropriation Act itself all show some ties to drought, but most legislation does not refer specifically to drought.

\section{Pre-1945 Legislation}

Legislation appeared in 1868 , during a drought, that enabled irrigation companies to take land and water, and construct canals. ${ }^{84}$ Appearing during an apparently non-drought period was water legislation in 1886 that attempted to establish the prior appropriation doctrine for water rights. ${ }^{85} 1899$ legislation during the 1892-1901 drought empowered irrigation companies to condemn property in aid of establishing reservoirs, lakes, or ponds for water storage. ${ }^{86}$ The legislature established the Kansas Water Commission in $1917^{87}$ during the decade-long drought. That commission was charged with investigating problems of, inter alia, domestic water supply and irrigation, establishing river gaging stations, and creating a general plan for development of river basins. ${ }^{88}$ Although the legislature repealed this act in $1927,{ }^{89}$ the act represented a major

81. Id. at 1360,1365 .

82. No. 98,280, 2008 WL 4140637, at*1 (Kan. Ct. App. Sept. 5, 2008).

83. Id. at *4.

84. GEN. STAT. OF KAN. ch. 23, § 89 (1868) (current version at KAN. STAT. ANN. § 42-120 (2012)).

85. An 1886 act allowed stream water to be appropriated and stated that first in time was to be first in right. 1886 Kan. Sess. Laws 154, ch. 115.

86. 1899 Kan. Sess. Laws 316, ch. 151.

87. 1917 Kan. Sess. Laws 218, ch. 172.

88. Id. at $219, \S \S 5,6$.

89. 1927 Kan. Sess. Laws 497, ch. 293, §§ 3, 6 (codified as amended at KAN. STAT. ANN. § 74$506 \mathrm{c}(2013))$. 
step in instituting water resources planning in Kansas. Near the end of that 1909-1919 drought, the 1919 legislature created the Division of Irrigation in the State Board of Agriculture, to be under the control of the Commissioner of Irrigation. ${ }^{90}$ The duties of the Commissioner included gathering data, visiting sites, and making quarterly reports to the State Board of Agriculture. ${ }^{91}$ Upon abolishing the Water Commission and the Division of Irrigation in 1927, the legislature created the Division of Water Resources (DWR) to assume their duties. ${ }^{92}$ DWR, under the direction of the chief engineer, remains today as the primary administrative body overseeing water rights in the State of Kansas. ${ }^{93}$

\section{The 1945 Water Appropriation Act}

Enacted just a few years after the severe drought of the "Dirty Thirties," 94 the 1945 Act itself made no express mention of drought. However, one author has stated that this Act was actively related to and ultimately resulted from the 1930's drought. ${ }^{95}$ It all began in 1939 when Governor Ratner appointed a committee and held a conference to study water resources problems and make recommendations. ${ }^{96}$ The committee report recognized the need for a state plan to control the water resources. ${ }^{97}$ In 1941, the legislature repealed the 1886 Act that had been the first stab at establishing the prior appropriation doctrine in Kansas and an administrative procedure for handling applications for water appropriation rights. $^{98}$ That 1886 attempt had been unsuccessful. ${ }^{99}$ A 1944 case, Kansas ex rel. Peterson v. Kansas State Board of Agriculture, ${ }^{100}$ affirmed the use of the common law doctrine of absolute ownership for groundwater.

90. 1919 Kan. Sess. Laws 297, ch. 218, §1.

91. Id. $\$ 4$.

92. 1927 Kan. Sess. Laws 497, ch. 293, $§ 2,3$ (codified as amended at KAN. STAT. ANN. $\S$ 74-506b, -506c (2013)).

93. Kan. Stat. AnN. § 82a-706 (2013).

94. The "Dirty Thirties," also known as the "Dust Bowl," refers to the 1930s drought. Kathy Weiser, 20th Century History: Dust Bowl Days or the "Dirty Thirties", LEGENDS OF AMERICA, http://www.legendsofamerica.com/20th-dustbowl.html (last updated Dec. 2012).

95. "In the fall of 1939 extreme drought conditions created a renewed interest in the water problems of Kansas and caused a re-examination of the state's water policies. The governor called a water conference in December of that year and [in 1944 another governor] ... appointed a committee to study and to investigate the water law of the state .... The Kansas legislature recognized the needs expressed by the Governor's committee; and the proposed act . . . became part of the law of this state in 1945." PFISTER, supra note 4, at 34-35.

96. Id. at 34 .

97. Id.

98. 1941 Kan. Sess. Laws 382, ch. 261, § 1.

99. See supra notes 44-52 and accompanying text.

100. 149 P.2d 604, 610-11 (Kan. 1944). 
The supreme court concluded that the chief engineer had been given no power over groundwater allocation. ${ }^{101}$ In response to this case, Governor Shoeppel appointed a committee to study the state water law. ${ }^{102}$ The resulting report, The Appropriation of Water for Beneficial Purposes: A Report to the Governor, ${ }^{103}$ published in December of 1944, recommended wholesale changes in Kansas water allocation law, and the legislature enacted the Water Appropriation Act the following summer. ${ }^{104}$ Although the report did not expressly give the 1930s drought as the sole underlying reason for the need for a change in water law, the report discussed the growth and effect of groundwater pumping during the low rainfall years of the 1930s, and the ensuing reductions in stream base flow caused by the combination of increased groundwater pumping and lower rainfall. ${ }^{105}$ The Act declared all water in the state to be dedicated to the use of the public; ${ }^{106}$ made "first in time, first in right" the basis for resolving conflicts among water right holders diverting from both surface water and groundwater; ${ }^{107}$ protected people using water from streams or groundwater on or prior to June 28,1945 , with "vested rights," 108 while stripping non-water-using landowners of their water rights; ${ }^{109}$ and later with amendments in 1957, declared that water rights are real property interests. ${ }^{110}$

\section{The Water Planning Acts}

Water resources planning in Kansas began in a serious way in 1917 when the legislature created the Kansas Water Commission to make a general plan for development of river basins. As stated above, ${ }^{111}$ the legislature abolished that commission in 1927, and the governor appointed boards in the early 1940s to

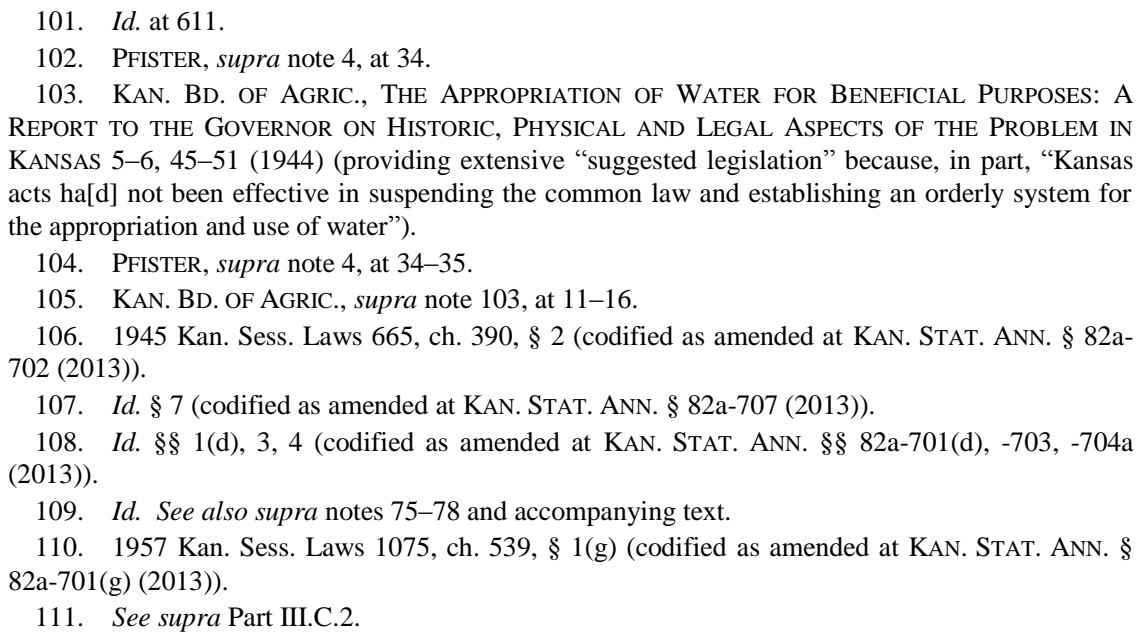


address issues regarding water rights doctrines. ${ }^{112}$ Modern water resources planning began in 1955 when the legislature created the Kansas Water Resources Board, led by the executive director. ${ }^{113}$ The board was charged with working out a state plan of water resources development. ${ }^{114}$ According to a 1977 governor's task force report, this activity occurred as a direct result of the 1951 flood and "one of the most severe droughts in Kansas history from 1952 through 1956." 115

During that same period, Congress passed the Federal Water Supply Act of $1958,{ }^{116}$ which permitted federal reservoirs to be sized for inclusion of additional storage capacity for municipal and industrial (M\&I) use in multipurpose federal reservoirs if "State or local interests shall agree to pay for the cost of such provisions." 117 Doing this legally in Kansas required a constitutional amendment. Kansans adopted an amendment in 1958, which permits the state to be a party to public improvements for "flood control works and works for the conservation and development of water resources"118 directed at alleviating the effects of drought. Indeed, Tuttle Creek Reservoir had originally been planned as a "dry dam," but the plans were modified after the 1952-1956 drought to include supply storage. ${ }^{119}$

\section{The Kansas Water Plan Storage Act}

Once Kansas agreed to repay the federal government for the additional conservation storage in reservoirs for M\&I purposes, the state had to have a way of obtaining the right to do so as against other established water rights on the rivers. It enacted the Water Plan Storage Act ${ }^{120}$ and developed the State Water Marketing Program. This program enabled the state to acquire "water reservation rights" for the purpose of diverting and storing the water in the reservoir $^{121}$ and to enter into long-term contracts with M\&I users to sell the

112. See supra Part III.C.3

113. 1955 Kan. Sess. Laws 724, ch. 356, § 1.

114. Id. $\S 4(2)$.

115. GOVERNOR'S TASK FORCE ON WATER RESOURCES, INTERIM REPORT OF THE GOVERNOR'S TASK FORCE ON WATER RESOURCES 5 (1977).

116. Pub. L. No. 85-500, Tit. III, § 301, 72 Stat. 319 (1958) (codified as amended at 43 U.S.C. $390 \mathrm{~b}(2012))$.

117. Id. §301(b).

118. KAN. CONST. art. XI, § 9.

119. KAN. WATER RES. BD., supra note 7, at app. G1-G2.

120. 1974 Kan. Sess. Laws 1514, ch. 452 (codified as amended at KAN. STAT. ANN. §§ 82a1301 to $-1376(2013))$.

121. Id. §§ 3-4 (codified as amended at KAN. STAT. ANN. §§ 82a-1303 to -1304 (2013)). 
water from storage. ${ }^{122}$ Receipts from the contracts enabled the state to repay the federal government in part. ${ }^{123}$ The word drought appears expressly in this legislation: the size of the state's water reservation right for any given reservoir is based on the yield sufficient for "a drought having a two percent (2\%) chance of occurrence in any one year" (i.e., a drought so severe that it occurs statistically only once in 50 years). ${ }^{124}$ However, the Act did not define the term drought.

\section{The Water Assurance District Act ${ }^{125}$}

The 1986 Water Assurance District (WAD) Act $^{126}$ emanated in part from a policy recommendation of the 1984 Kansas Water Plan: "The state should attempt to enhance streamflows, using reservoir water, through moderate droughts. ..."127 The idea was to gain more control over the operation of federal reservoirs than was then possible, all " $[\mathrm{t}]$ o fully realize the benefits from reservoir storage...."128 As explained in another part of the 1984 Kansas Water Plan, the 1983 drought had created an acute situation on the Verdigris River. ${ }^{129}$ That, coupled with a lack of interest in the State Water Marketing Plan, had indicated problems "in the distribution of reservoir water supply benefits during drought periods." $" 130$ The Kansas legislature enacted the WAD Act in 1986, enabling M\&I users downstream from federal reservoirs to join together in a WAD, issue bonds, and aid the state in repaying the federal government for adding conservation storage in these reservoirs. ${ }^{131}$ In return, these WAD members were promised reservoir releases sufficient to meet certain prescribed target flows on the river. ${ }^{132}$

122. Id. $\S \S 5-8$ (codified as amended at KAN. STAT. ANN. §§ 82a-1305 to -1308a (2013)).

123. See id. § 15 (codified as amended at KAN. STAT. ANN. § 82a-1315b(b) (2013)).

124. Id. § 3 (codified as amended at KAN. STAT. ANN. § 82a-1303(a) (2013)).

125. See generally John C. Peck, Kansas Water Assurance Districts, 40 U. KAN. L. REv. 903, 915-20 (1992) (describing the history of the Water Assurance District Act and explaining its provisions).

126. 1986 Kan. Sess. Laws 2023, ch. 391 (codified as amended at KAN. Stat. ANN. §§ 82a1330 to -1347 (2013)).

127. Kan. Water OfF., Kansas Water Plan: Minimum Desirable Streamflows 5 (1984).

128. Id. at 4 .

129. Kan. Water OfF., Kansas Water Plan Management Section: Assurance PROGRAM 3 (1984).

130. Id

131. 1986 Kan. Sess. Laws 2023, ch. 391 (codified as amended at KAN. STAT. ANN. §§ 82a1330 to -1347 (2013)).

132. Id. $\S 16$ (b) (codified as amended at KAN. STAT. ANN. § 82a-1345(b) (2013)); Peck, supra note 125 , at $924,930-31,933-36$. 


\section{Amendments to the 1945 Kansas Water Appropriation Act}

Several amendments to the 1945 Water Appropriation Act have helped address drought issues: conservation plans, minimum desirable streamflow, and multi-year flex accounts.

\section{a. Conservation Plans}

In 1986, the legislature amended the Appropriation Act to give the chief engineer power to require permit applicants to "adopt and implement conservation plans and practices." 133 The Division of Water Resources (DWR) followed in 1989 with an administrative policy stating that DWR would condition approval of both appropriation permit applications and change applications with a requirement to adopt conservation plans. ${ }^{134}$ In 1991, the legislature amended the Appropriation Act with a section permitting the chief engineer to require permit applicants - as well as holders of established water rights - to adopt and implement conservation plans and practices, to be consistent with guidelines prepared by the Kansas Water Office pursuant to K.S.A. 74-2608(c) ${ }^{135}$ For times of low flow, the guidelines for municipal users, for example, suggest reducing or banning nonessential uses, imposing rationing, and, with the aid and authority of DWR, imposing pumping restrictions by private well owners inside the city. ${ }^{136}$

\section{b. Minimum Desirable Streamflows (MDS)}

MDS legislation in 1984 and 1985 came about through Kansas Water Office (KWO) State Water Plan recommendations. ${ }^{137}$ MDS on specific streams could be achieved in part by water assurance district releases and in part by having the state set aside and withhold from appropriation certain flows at specific points on rivers and streams. ${ }^{138}$ The 1985 legislation also set out a table

133. 1986 Kan. Sess. Laws 2031, ch. 392, § 3(d).

134. Div. OF WATER ReS., Admin. Pol. No. 89-1 (Jan. 1989).

135. 1991 Kan. Sess. Laws 1605 , ch. 292, § 5 (codified as amended at KAN. STAT. ANN. § 82a$733(2013))$.

136. Kan. Water OfF., 2007 Kansas Municipal Water CONSERVATiOn Plan Guidelines 9-13 (2007), available at http://www.kwo.org/projects_programs/WaterConservationEducation/ rpt_2007\%20WCP_Guidelines_081507_ms\%20.pdf.

137. See KAN. WATER OFF., supra note 127 (describing "procedures of establishing, monitoring and administering minimum desirable streamflows").

138. 1985 Kan. Sess. Laws 1446, ch. 338, § 1 (codified as amended at KAN. STAT. ANN. § 82a703a (2013)). 
showing these MDS values for specific streams and times of the year. ${ }^{139}$

\section{c. Multi-year Flex Accounts}

Created in 2001 as K.S.A. 82a-736, with several amendments to that section since then, this concept provides flexibility to water right holders, especially irrigators, by allowing them to exceed their permitted annual pumping quantities in dry years, but with a five-year limit based on the water right's five-year total permitted quantity. ${ }^{140}$ In the drought of 2011 and 2012, DWR adopted special rules that permitted a variation on the five-year multi-year flex accounts: DWR issued two-year drought emergency permits to give an irrigator the chance to borrow for year 2011 from the irrigator's 2012 quantity. ${ }^{141}$

\section{Miscellaneous Statutes Dealing Specifically with Drought}

Several other statutes expressly mention drought. These involve several levels of government and the insurance industry.

\section{a. Kansas Water Office}

K.S.A. 82a-928 requires the KWO to adopt water plan policies to achieve long-range goals, including "the design of municipal water systems to provide an adequate water supply to meet the needs of a drought having a $2 \%$ chance of occurrence." ${ }^{142}$ A follow-up section permits the KWO to acquire water reservation rights to store water in federal reservoirs in quantities sufficient to insure a yield of water from the reservoir based on the same two percent chance of occurrence of a drought. ${ }^{143}$ K.S.A. 74-2608(c) requires the KWO to develop and maintain guidelines for water conservation plans and practices and to establish guidelines as to when drought conditions exist. K.S.A. 82a-1414(b) permits the director of the KWO to grant weather modification permits on an emergency basis during droughts without prior publication of required notices.

139. Id. $§ 2$. (codified as amended at KAN. STAT. ANN. $§ 82 \mathrm{a}-703 \mathrm{c}(2013)$ ).

140. 2001 Kan. Sess. Laws 1409, ch. 160, § 16 (codified as amended at KAN. STAT. ANN. § 82a$736(2013))$.

141. John C. Peck, Water Law, 23 KANSAS ANNUAL SURVEY 361, 367-68 (2012).

142. KAN. STAT. ANN. § 82a-928(q) (2013). When enacted in 1965, this duty was vested in Kansas Water Resources Board. 1965 Kan. Sess. Laws 1252, ch. 558.

143. See supra text accompanying notes 120-24. 


\section{b. Counties and Municipalities}

With the permission of the county commission, a county may provide access to water in reservoirs during times of drought ${ }^{144}$ and may spend money for pump and well equipment to be used during drought emergencies. ${ }^{145}$ Counties were active during the 1930s drought in "sponsoring the construction of dams and wells on private farms with the use of federal emergency work relief funds, and lending county equipment for such projects." ${ }^{, 16}$ In the drought of the 1950's, counties purchased pumping and other equipment to construct and maintain drought relief wells and emergency water supply projects. ${ }^{147}$ K.S.A. $12-16,117$ states that municipalities ${ }^{148}$ providing assistance to other municipalities and public safety agencies in times of disaster, including drought, are subject to all laws "including those providing immunity from liability, as if such municipality . . . was acting within such municipality."149 While municipalities ${ }^{150}$ are generally subject to the cash-basis law, ${ }^{151}$ an exception is made for "municipally owned and operated utilities" for meeting expenditures in excess of current revenues "caused by, or resulting from the meeting of, extraordinary emergencies including drought emergencies." 152

\section{c. The Governor}

The governor is responsible for "meeting the dangers to the state and people presented by disasters", ${ }^{153}$ is authorized to declare a proclamation that a state of drought exists in specific areas or communities or statewide; ${ }^{154}$ and is required to "effect immediate implementation of drought contingency plans contained in state approved conservation plans." ${ }^{155}$ A KWO website lists press releases that

144. KAN. STAT. ANN. § 82a-408 (2013).

145. Id. $\S \S 19-3001$ to -3004 .

146. Marcene Grimes, U. Kan. Governmental Res. Ctr., Government \& Natural RESOURCES IN KANSAS: WATER 47 (1957).

147. See id. (discussing several counties' use of a 1941 drought relief law to "provide farmers with water from ... wells during the current [1950s] drought").

148. Here municipalities refers to cities, counties, and townships. KAn. Stat. ANn. § 1216,117(a)(1) (2013).

149. Id. at (c).

150. Here municipalities refers to "any county, township, city, municipal university, school district, community college, drainage district and any other taxing district or political subdivision of the state which is supported with tax funds." KAN. STAT. ANN. § 10-1101(a) (2013).

151. Id. $\S-1102$.

152. Id. $\S-1116 \mathrm{a}(\mathrm{a})$.

153. Id. § 48-924(a).

154. Id. at (e).

155. Id. 
describe various actions taken by the governor and others during the drought in 2012. ${ }^{156}$ A partial list includes a drought emergency declaration that triggered access to additional water storage, disaster declarations for thirty-seven counties, federal disaster declarations for eighty-seven drought-stricken counties, and an updating of Kansas drought areas. ${ }^{157}$

\section{d. Boards of Education}

The state board may waive rules on duration of school years in case of disasters, including droughts. ${ }^{158}$ Local boards may participate in disaster relief programs, including drought programs. ${ }^{159}$ K.S.A. $72-6458$ creates rules for eight specified school districts in which disaster emergencies (including drought) have been declared. ${ }^{160}$

\section{e. Soil Conservation Districts}

Background reasons for establishing soil conservation districts are shown in K.S.A. 2-1902. This somewhat ambiguous section lists some consequences of soil erosion, including "a diminishing of the underground water reserve, which causes water shortages, intensified periods of drought, and causes crop failures."

\section{f. Insurance}

Legislation enacted in $1927^{162}$ and $1931^{163}$ allows stock fire insurance companies and mutual fire and tornado insurance companies, respectively, to insure property against loss by drought.

156. Kansas Drought: Press Releases, KAN. WATER OFF., http://www.kwo.org/reports_ publications/drougt.htm (last visited Mar. 13, 2014). See also infra text accompanying note 185.

157. Kansas Drought: Press Releases, supra note 156.

158. KAn. STAT. ANN. § 72-1106e (2013).

159. Id. $\S-8234$.

160. These rules deal with computing general fund budgets based on adjusted enrollments.

161. Kan. Stat. AnN. § 2-1902(B) (2013).

162. 1927 Kan. Sess. Laws 294, ch. 231, arts. IX-X (codified as amended at KAn. StAT. ANN. $\S \S 40-901$ to -1029 (2013)).

163. 1931 Kan. Sess. Laws 307, ch. 206 (codified as amended at KAN. Stat. ANN. § 40-1027 (2013)). 


\section{Administrative Agencies}

DWR, ${ }^{164}$ the KWO, ${ }^{165}$ and groundwater management districts ${ }^{166}$ have administrative regulations that refer specifically to drought, and these agencies deal with drought in various ways.

\section{The Division of Water Resources}

DWR is charged ${ }^{167}$ with granting new water rights permits ${ }^{168}$ and change orders, ${ }^{169}$ and has authority to condition permits and change orders. ${ }^{170}$ It can thus add conditions to an appropriation permit to divert water from a river-for example, to preserve flow in the river during drought or when the flow reaches a prescribed low level. An example is the permit issued by DWR in 1982 to KP\&L for the Jeffrey Energy Center for water from the Kansas River. ${ }^{171}$ After a hearing and testimony from interested parties including water right holders and others affected, DWR conditioned the permit to disallow any diversion when the flow of the Kansas River is less than 900 c.f.s. ${ }^{172}$

DWR also administers water rights during drought periods. ${ }^{173}$ An example

164. KAN. ADMIN. REgS. § 5-1-1(yy) (2014) (defining "perennial stream" with regard to "drought"); id. § 5-7-1(a)(2) (finding due and sufficient cause for nonuse of a right, established or being perfected, for certain supplies likely subject to depletion during "drought"); id. § 5-15-1(d)(4) (naming the effects of "drought" as a consideration for administering MDS).

165. Id. § 98-1-1(i), (u), (z) (defining "drought having a two percent chance of occurrence in any one year," "reservoir yield" and "water reservation right" using "drought"); id. § 98-5-4(h)(5) (considering "drought" in defining the conditions necessary to approve a water plan storage contract); id. § 98-5-9 (explaining reservoir yield calculation with reference to "drought").

166. Id. § 5-22-1(hh) (defining "stream" with regard to "drought"); id. § 5-25-1(k) (defining "stream" with regard to "drought").

167. KAN. STAT. ANN. § 74-506b (2013).

168. Id. § 82a-711.

169. Id. $\S-708 \mathrm{~b}$.

170. Id. $\S-711 \mathrm{a}$.

171. Application, File No. 34,442, of Kan. Power \& Light Co. for Permit to Appropriate Water for Beneficial Use (Div. of Water Res., Kan. Bd. of Agric. Apr. 30, 1982).

172. Id. at $15, \llbracket 66$.

173. Legislation also permits DWR to establish intensive groundwater use control areas (IGUCAs) when groundwater levels are declining excessively. KAN. STAT. ANN. § 82a-1038 (2013). To date, DWR has established nine IGUCAs. Intensive Groundwater Use Control Areas, KAN. DEP'T OF AGRIC., http://agriculture.ks.gov/divisions-programs/dwr/managing-kansas-waterresources/intensive-groundwater-use-control-areas (last visited Mar. 13, 2014). Because the focus of the IGUCA is groundwater decline, the hearings typically do not contain information about drought. Id. However, three of the nine IGUCAs were formed during or following drought periods. The order establishing the IGUCA in McPherson County in 1980 made no mention of the drought or climatic conditions, concluding only that groundwater levels were declining. See Proposed Designation of an Intensive Groundwater Use Control Area in McPherson Cnty., Kan., 13 (Div. of Water Res., Kan. Bd. of Agric. Mar. 28, 1980). Similarly the order establishing an IGUCA in 
from 2009 was the administration of junior water rights in favor of a senior right in Stevens County. ${ }^{174}$ The chief engineer's order required the impairing junior users to prepare conservation plans and limited their pumping to $80 \%$ of their authorized annual use until further notice. ${ }^{175}$ Recently, DWR has also administered MDS on several streams - the Smoky Hill River and tributaries, the Little Arkansas River and tributaries, the Walnut River and tributaries, the Chikaskia River, the Medicine Lodge River, portions of the Ninnescah River, portions of the Neosho River and its tributaries including the Cottonwood River. ${ }^{176}$

During the 2011 drought, DWR offered two alternatives to allow additional pumping-multi-year flex account permits and drought emergency permits. ${ }^{177}$ While flex-accounts were already part of water appropriation law, the emergency term permits "allowed holders of existing water rights the flexibility to 'borrow a portion of next year's authorized quantity in order to complete the 2011 growing season." $" 178$

DWR has mandated cities, other public water suppliers, industries, and irrigators to adopt conservation plans. ${ }^{179}$ During the recent, serious drought in the Wichita area in 2012 and 2013, Wichita considered amending its plan with measures such as publication of water conservation tips, bans on outdoor water usage, imposition of flow restrictors, and imposition of large fines. ${ }^{180}$ The city,

Wallace, Logan, Gove and Trego Counties concluded that the declining streamflows were primarily due to the effects of increased conservation practices and effects of groundwater water and surface water pumping in the alluvial valley. See Designation of an Intensive Groundwater Use Control Area in Wallace, Logan, Gove and Trego Cntys., Kan., 13-14 (Div. of Water Res., Kan. Bd. of Agric. July 20, 1988). In the late 1980s the chief engineer initiated another IGUCA proceeding, this one in the Walnut Creek area of west-central Kansas. See Designation of an Intensive Groundwater Use Control Area in Barton, Rush and Ness Cntys., Kan. (Div. of Water Res., Kan. Bd. of Agric. Mar. 13, 1990). The state held early surface water rights for water from Walnut Creek and the Arkansas River, but was not able to obtain sufficient water under these rights to provide water to the Cheyenne Bottoms Wetland. Id. at 1-3, IIII 1-4. Although this proceeding was initiated and concluded during the 1988-1992 drought period, the chief engineer concluded that most of the declines in streamflow were not a result of general climatic changes because the precipitation had not changed significantly. Id. at 20, If 2 . More responsible than the climate for streamflow declines were conservation measures like ponds and tillage practices, watershed structures, and alluvial groundwater pumping in the Walnut Creek Basin. Id. at 96, II 4. See In the Matter of the Designation of an Intensive Groundwater Use Control area in Barton, Rush, and Ness County, Kansas, Jan. 29, 1992 (testimony of James Bagley in formal phase, and Conclusions 1, 3, \& 4).

174. John C. Peck, Water Law, 21 Kansas ANnUAL SuRVey 355, 360-61 (2010).

175. Id.

176. Peck, supra note 141 and accompanying text.

177. Id. at 367.

178. Id.

179. See supra notes $135-36$ and accompanying text.

180. Bill Wilson, City of Wichita Proposes Water-use Plan in Case of Future Drought, Wichita EAGLE, Aug. 27, 2013, http://www.kansas.com/2013/08/27/2967825/city-of-wichita- 
however, faced opposition. ${ }^{181}$ The drought ended with large rainfall totals that helped fill Cheney Reservoir, but the city passed an ordinance that adopted the "Drought Response: Stages \& Action Steps," which established four stages of drought seriousness, adopted many of the proposed amendments, but not a proposal to impose up to $\$ 1,000$ fines for repeat violators. ${ }^{182}$ Johnson County Water District No. 1 deals with various drought effects with a proactive and aggressive plan to repair water line breaks and through online instructions for its customers on using water wisely. ${ }^{183}$ Rural Water District No. 7 of Johnson County, Kansas, issues news releases that encourage conservation during droughts. ${ }^{184}$

\section{The Kansas Water Office}

As required by K.S.A. 74-2608(c), the KWO has promulgated Guidelines for Conservation Plans and Practices. These guidelines are available online, ${ }^{185}$ and as stated above in Part III.D.1, DWR has mandated many water right holders to adopt conservation plans. ${ }^{186}$

For several years in the late 1980s, the KWO conducted "drought exercises" for four rivers: the Kansas, Marais des Cygnes, Neosho, and Verdigris Rivers. ${ }^{187}$ These exercises were "an attempt to evaluate reliability of existing water supply

proposes-water.html.

181. Bill Wilson, Wichita Reviews Water Conservation Plan in Wake of Drought's End, Wichita EAGLE, Nov. 28, 2013, http://www.kansas.com/2013/11/29/3147476/wichita-reassesseswater-conservation.html ("In February, city officials announced that Cheney Reservoir would run dry in 2015 if the drought continued. They launched conservation efforts, primarily structured around education and rebates to water users with energy efficient appliances. A proposal for huge fines - up to $\$ 1,000$ for chronic big water users - sparked a community outcry and a split between the council and administration. Instead, smaller financial penalties were built in to the city's drought plan.").

182. City of Wichita, Drought Response: Stages \& Action Steps (2013), http://wichitaks.granicus.com/MetaViewer.php?view_id=2\&clip_id=2317\&meta_id=125052.

183. Use Water Wisely, WATER ONE, http://www.waterone.org/community/use-water-wisely (last visited Mar. 13, 2014).

184. News, W7, http://www.water7.com/newsupdates/ (last visited Mar. 13, 2014).

185. See generally Reports and Publications, KAN. WATER OFF., http://www.kwo.org/reports_ publications/Reports_Publications.htm (last visited Mar. 13, 2014).

186. See, e.g., KAN. WATER OFF., 1986 KANSAS INDUSTRIAL WATER CONSERVATION PlaN GUIDELINES (1986), http://www.kwo.org/reports_publications/Reports/RPT_1986_Kansas_ Industrical_Water_Conservation_Plan_Guideline_091307_sj.pdf; KAN. WATER OFF., 2007 KANSAS MuniciPAL WATER CONSERVATION PlAN Guidelines (2007), http://www.kwo.org/reports_ publications/Reports/rpt_2007\%20WCP_Guidelines_081507.pdf; KAN. WATER OFF., 2006 KANSAS IRRIGATION WATER CONSERVATION PLAN GUIDELINES (2006), http://www.kwo.org/reports_ publications/Reports/Rpt_2006_KS_Irrig_WC_Guidelines.pdf.

187. E-mail from Tom Stiles, Chief, Watershed Planning Sec., Bureau of Water, Kan. Dep't of Health \& Env't, to author (Feb. 18, 2014, 10:20 CST). 
mechanism, water rights and water marketing programs ... in repeat of [the] fifties drought." 188 Participants in the Kansas River exercise, for example, were the KWO, DWR, the Corps of Engineers, and major M\&I water right holders along the river. ${ }^{189} \mathrm{~A}$ mass balance model of available water from the river and reservoirs was run against 1950 s drought conditions, month to month. ${ }^{190}$ Everything was fine until Bowersock Mills \& Power Co., Inc., of Lawrence, the holder of a vested right for 1,000,000 acre-feet of water per year for hydropower production on the Kansas River, exercised its vested right to increase flow in the river and to by-pass inflows through Milford, Tuttle Creek, and Perry Reservoirs. ${ }^{191}$ That brought the system into "crisis management in short order." 192 These exercises were part of the impetus behind developing water assurance districts ${ }^{193}$ on the Kansas, Marais des Cygnes, and Neosho Rivers. ${ }^{194}$ More recently, in 2001, the KWO announced development of a drought exercise for water assurance district members using a new OASIS Kansas River Reservoir Model and demonstrated to WAD members how it would work. ${ }^{195}$

The KWO has also developed the program called Drought Planning and Response and a useful website that provides web links, "fact sheets," maps and periodic updates on current drought conditions, and extensive program information on drought monitoring, preparedness, and response. ${ }^{196}$ KWO Fact Sheet No. 13a, for example, on drought preparedness, contains information that includes "State and Local Actions" under the following headings: (1) "Drought Vulnerable Public Water Suppliers," (2) "Municipal Water Conservation Plans," (3) "Water Marketing and Water Assurance Programs," (4) the "Multipurpose Small Lakes Program," (5) "Public Wholesale Water Supply Districts," (6) "Minimum Desirable Streamflow," and (7) "Public Water System Capacity Development."197 Fact Sheet No. 13b on drought response discusses "who's responsible" for what. ${ }^{198} \mathrm{KWO}$ is responsible for drought monitoring. ${ }^{199} \mathrm{KWO}$

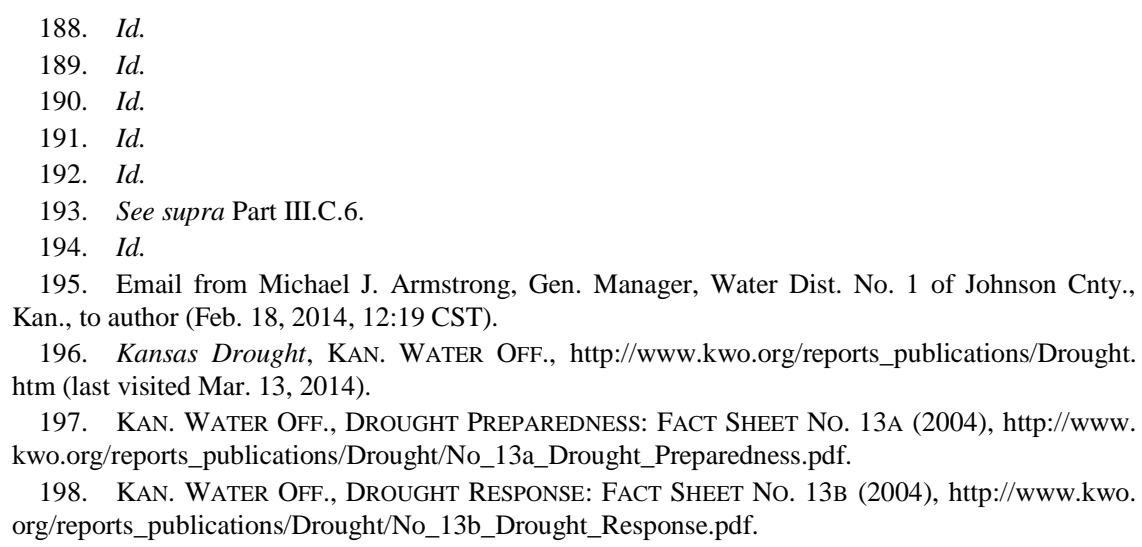

197. Kan. Water OfF., Drought Preparedness: Fact Sheet No. 13a (2004), http://www. kwo.org/reports_publications/Drought/No_13a_Drought_Preparedness.pdf.

198. Kan. Water OfF., Drought Response: Fact SheEt No. 13B (2004), http://www.kwo. org/reports_publications/Drought/No_13b_Drought_Response.pdf. 
uses the U.S. Drought Monitor, which was introduced in 1999 and which utilizes the Palmer index. ${ }^{200}$ This fact sheet also describes the Governor's Drought Response Team, which consists of eleven members assembled upon KWO's advice. ${ }^{201}$ Executive Order 03-17 approved the Operations Plan for the Governor's Drought Response Team, including a three-step phased response approach: Drought Watch, Drought Warning, and Drought Emergency. ${ }^{202}$ The KWO website provides more details about the Governor's Drought Response Team and the Kansas Adjutant General's Department, Kansas Division of Emergency Management, which has authority in situations requiring immediate response-e.g., the need for pumps and pipe. ${ }^{203}$

\section{CONCLUSION}

The purpose of this article has been to provide a brief look at legal responses to Kansas drought. A future article might analyze how the drought responses in Kansas compare to responses in other states, and it could also cover legal responses to floods, which have had equally damaging effects on Kansas. Ascribing legal activities-judicial decisions, legislation, and administrative action-as responses to drought is not a certain process unless the term drought is expressly stated in the case, legislation, or background information. Examples include some of the cases described during the droughts of 1909-1919 and 1929-1941, and legislation such as the 1986 Kansas Water Assurance District Act, which came about in part because of a Kansas Water Plan recommendation on drought response. The most direct responses to drought have been the recent administrative activities carried out by DWR, the KWO, and the governor.

Kansas has suffered many serious droughts, and there is no reason to think that these will not continue in the future. Although climate change may produce more rainfall in some places and less in others, there is apparently little consensus on exactly where these geographical areas will be. ${ }^{204}$ Some climate change predictions, however, suggest that more serious droughts are in the

\footnotetext{
199. Id.

200. Id. See also supra note 39.

201. KAN. WATER. OFF., supra note 198.

202. Id.

203. Id

204. See, e.g., Justin Gillis, Science Linking Drought to Global Warming Remains Matter of Dispute, N.Y. TIMES, Feb. 16, 2014, http://www.nytimes.com/2014/02/17/science/some-scientistsdisagree-with-presidents-linking-drought-to-warming.html?_r=0 (suggesting that President Obama's ascribing California's recent drought to human-induced climate change is "pushing at the boundaries about the scientific relationship between climate change and drought," with one scientist concluding that the severity of the drought is due to "natural variability").
} 
offing in places like the Great Plains area of the U.S. For example, in an article that synthesizes a number of scientific reports, the U.S. Global Change Research Program makes the following statements:

Projected changes in long-term climate and more frequent extreme events such as heat waves, droughts, and heavy rainfall will affect many aspects of life in the Great Plains. ...

$\cdots$

Projections of increasing temperatures, faster evaporation rates, and more sustained droughts brought on by climate change will only add more stress to overtaxed water sources. Current water use on the Great Plains is unsustainable, as the High Plains aquifer continues to be tapped faster than the rate of recharge. ...

$\cdots$

With limited water supply comes increased vulnerability of agriculture to climate change. Further stresses on water supply for agriculture and ranching are likely as the region's cities continue to grow, increasing competition between urban and rural users. ...

$\cdots$

... For everyone on the Great Plains, though, a changing climate and limited water supply are likely to challenge their ability to thrive, leading to conflicting interests in the allocation of increasingly scarce water resources. ${ }^{205}$

If these predictions of increased drought periods materialize, the efficacy of drought response programs in Kansas will be further tested.

205. U.S. Global Change Research Program, Global Climate Change Impacts in the United States 2009 RePORT: GReat Plains 123, 123, 124, 126, 128 (2009) (citations omitted), http://downloads.globalchange.gov.usimpacts/pdfs/great-plains.pdf. According to an op-ed piece in the New York Times, "climate change has been leading to global conflict-and even the collapse of civilizations - for more than 3,000 years." Professor Eric H. Cline also states that "a centuries-long drought in the Aegean and Eastern Mediterranean regions, contributed to-if not causedwidespread famine, unrest and ultimately the destruction of many once prosperous cities, according to four recent studies." Eric H. Cline, Climate Change Doomed the Ancients, N. Y. TIMES, May 28, 2014, at A21, available at http://www.nytimes.com/2014/05/28/opinion/climate-change-doomedthe-ancients. html?_r=0. 